\title{
THE ACCESSIBILITY OF TRANSPORTATION TO SUPPORT TOURISM IN THE MUNICIPALITY OF MENTAWAI ISLANDS \\ Lut Mafrudoh ${ }^{1}$, Simon Gultom ${ }^{2}$, Sekar Widyastuti Pratiwi ${ }^{3}$, Prima Widiyanto 4
}

1. STMT Trisakti, 2. STMT Trisakti, 3.STMT Trisakti, 4. STMT Trisakti

$\triangle$ corresponding author: luthe.mafrudoh@gmail.com

\begin{abstract}
The Municipality of Mentawai Islands is the only regency in West Sumatra Province in a form of islands which has different regional characteristics with other cities and regencies in the province. It consists of a small and large group of 99 islands surrounded by the Indian Ocean. The distance between the Municipality of Mentawai Islands and the provincial capital of Padang is about 62 nautical miles. Sea and air transports become main transportation. However, sea transport is often used rather than air transport. The only route of air transport is from Rokot to Padang and otherwise using small plane (Susi Air). Based on the results of the research, the transportation costs to experience the significant resources of Mentawai Islands with its natural scenery and underwater beauty is expensive due to the inadequate of transportation accessibility.
\end{abstract}

Keywords: Accessibility, Transportation, and Tourism

\section{Introduction}

The vast growth of tourism industry has attracted a large amount of attention from most provinces as well as municipalities in Indonesia to catch a bigger portion of this economic activity. They are competing to build transportation access such as ports, airports, highways, and other supporting facilities in order to boost their economic growth and elevate the number of tourists visiting their areas.

Tourist Destination - also called as Daerah Tujuan Wisata (DTW) in Bahasa Indonesia - is traditionally defined as a geographic area as in a country, an island, or a city. Tourist destination is currently a part of spatial area appointed based on tourism potential of the area which can be classified into five factors of potentials: (1) accommodation and facilities including hotels, restaurants, travel agents, tourists guides, recreational facilities; (2) cultural attractions including components of historic relics and archeology, local language and customs, paintings, artworks and carvings, architectural 
works and landscape, and tribes; natural attractions including components of flora and fauna, landscape, mountains, lakes, rivers and sea/beaches; (4) economic condition including the number of domestics and foreign investments as well as commerce; (5) accessibility including roads, railways, ports, airports (M, 2011).

The same thing happens in the Municipality of Mentawai Islands. One of the island regency in West Sumatra that has plenty of tourism sites, mangrove forest, beautiful coral reefs, small islands, and unique traditions. Mentawai Islands is well-known for having plenty marine resources, and fishery, so that it becomes the basic capital in regional development.

In order to develop a certain area into a tourist destination cannot depend only on natural beauty and accommodation, but there are also some supporting elements that should be obtained.

A well-managed accessibility will determine whether or not a location can be reached. Besides, transportation is also one of the influential elements that affect the important smoothness of public service (Sumarabawa, 2013).

\section{Literature Review}

Transportation, is a field of activity that is very important in the life of Indonesian people and even the world. The importance of transportation for the people is caused by several factors, among others, the geographical condition of Indonesia which consists of thousands of small and large islands (archipelago); waters composed mostly of seas; rivers and lakes that allow transport by land and water and air to reach all parts of Indonesia. Thus, Indonesia is the largest archipelagic country in the world, with a sea area of $2 / 3$ of its total territorial area. Another thing that is equally important to the needs of transportation is the need for comfort, safety and smoothness transportation that supports the implementation of development in the form of distribution of development needs, equity of development, and distribution of development outcomes in various sectors to all corners of the 
country such as industry, trade, tourism and education. (Muhammadiyah \& Majid, n.d.).

Air transport industry and tourism are complemented each other. Tourism depends on transportation to bring visitors, whilst the transportation industry depends on tourism to generate demand for its services. The growth in tourism industry directly reflects onto the air transportation. Over the last 25 years, the number of international tourists has more than doubled. The expansion of international tourism has a large impact on the discipline of transport geography. Transport is the cause and the effect of the growth of tourism. To start with, the improved facilities have stimulated tourism, and the expansion of tourism has stimulated transport. Accessibility is the main function behind the basics of tourism transport. In order to access the areas that are mainly aimed, tourists will use any transportation mode. (Ricardianto, Djajaputra, \& Martono, 2017) Accessibility is the main function in tourism transport. To access a location of the main destination, tourists will use modes of transportation. The relation of tourism and transportation specially affected by two elements; convenient access and transportation service quality which has to fulfill the expectation of the users as in security, comfort, frequency, efficiency and reliability (Tambunan, 2009).

The main function of transportation has a very close connection with accessibility. Accessibility is related to usage frequency and speed of the transports, so that the mileage would seem to be shorter. This means reducing the travelling time, therefore, it would lighten the travelling cost. Hence, it can be said that transportation can make it easier for people to visit a certain area, for example, a tourist destination (Tambunan, 2009). The defining factors of success in developing a tourist destination involve 3 factors, those are: (1). The availability of attractions, whether they are natural attractions, such as the beaches or the man-made attractions including objects or other unique attractions that come from the local people. (2). The 
accessibility to and during the stay in a certain tourist destination, and (3). Factors that offer convenience for tourists like the availability of accommodation, restaurants, bars, and also other supporting facilities that are needed to allow the tourists to enjoy their stay in a certain tourist destination (Pgri \& Barat, 2015).

Any kind of tourist attractions, accessibilities and facilities and services that are available in a tourist destination can satisfy the need and the will of tourists during their stay in a tourist destination (Pgri \& Barat, 2015).

Infrastuctures are any facilities which enable the process of economy to run so smoothly that it makes people easy to fulfill their needs. Tourism infrastructures are natural resources and human resources which are absolutely needed by the tourists in their travel to the tourist destination, such as road, electricity, water, telecomunication, health services, terminal/harbour, and so on (Simarmata \& Keke, 2017)

\section{Method}

This study was a descriptive study that used surveys. The study was conducted to provide descriptions, systematic pictures or overviews, accurate and factual concerning to the facts, characteristics as well as relation amongst observed phenomena. The objective of this study is to identify tourists' attractions and the tourism accessibility in the Municipality of Mentawai Islands, West Sumatera.

In this study, data were collected by doing observations and interviews. Interviews were done to respondents that were related to topic of this study such as passengers of ships and airplanes, representative from ASDP Indonesia Ferry, port officers, representative from Department of Transportation, representative from Provincial Tourism Office and local figures. 


\section{Discussion and Results}

\subsection{Tourist Attractions in the Municipality of Mentawai Islands}

The main characteristic of Mentawai Regency is the white sandy beaches, beautiful islands, coral reefs, and remarkable waves. It will be easy to find coral reefs along the east, south and southeast coast of the island. The right place for sunbathing, swimming, snorkeling, and diving. Malisok Beach in south Siberut looks like a bay full of palm trees. Beautiful marine parks are found in the western area including in Pokai Bay and Katurei Bay. Another activity that can be done is animal observation, especially mangrove forest dwellers such as non-poisonous pythons. Surfing is also quite popular in Mentawai Regency recently. With its 4 meter-wave height and 6 times wave breaks, Mentawai is now become popular among international surfers from Australia, Japan, USA, New Zealand and also domestic surfers from Bali and North Sumatera.

\subsection{Natural Tourism}

The uniqueness of nature possessed by Mentawai Islands has become an interesting site for tourists to visit. It is shown in a chart of natural tourisms that exist in Mentawai Islands. The tourist destinations that can be visited are: Sitamtaman water fall, in Moganpoula village, North Siberut, Kulubuluk water fall in Madobak village, south Siberut, Cimpungan water fall in Cimpungan village, Central Siberut, Lake Gojib in Simalegi village, Wes Siberut, Siberut National Park, Siberut Island, and endemic primates of Mentawai, Siberut Island.

The authenticity of Mentawai nature with rare flora and fauna has become another reason for travellers and scientists to come to the island. In order to preserve Mentawai forests, Indonesian Ministry of Forestry has announced the establishment of TNS (Taman Nasional Siberut) or Siberut National Park that based in Muara Siberut Village, South Siberut. 


\subsection{Marine Tourism}

Mentawai has $6,011.35 \mathrm{~km}^{2}$ land area and approximately $10,099.44 \mathrm{~km}^{2}$ measured 4 miles out at low tide against the outermost islands. Cluster of islands with approximately 100 islands; consist of 1 big island of Siberut island and 99 smaller islands spreading from the north to south. From several islands in Mentawai Regency, there are four islands inhibited, those are Siberut Island, Sipora Island, North Pagai Island, and South Pagai Island. Siberut Island with an area of $4.030 \mathrm{~km}^{2}$ is the largest island amongst the islands in Mentawai Regency. As the other three smaller islands are Sipora Island $(845 \mathrm{~km} 2)$, North and South Pagai $(1,675 \mathrm{~km} 2)$ located to the South of Siberut island. With the advantage of being an archipelago, Mentawai Islands is very potential to develop its marine tourism. As the international tourist destination, surfing has introduced Mentawai Islands internationally. Some international surfers have even compared the beauty of Mentawai waves to the Hawaii waves. It has been recorded that the Municipality of Mentawai Islands has over 70 well-known surfing spots which attracted tourists from all over the world. There are 42 exclusive surfing spots that become the target of world surfers with the wave height of about $3-6$ meters.

\subsection{Cultural Tourism}

Cultural Tourism in Mentawai Islands is established in Madobag, Ugai, Butui, Matotonan, Lita, Sagulube', Taileleu. In those areas, tourists are able to relish the uniqueness of daily routines of the original Mentawai's people who live in their traditional custom of 'Sabulungan'. Some scientists have written that Mentawai culture is parallel to Colere which comes from a Latin word that means caring, nurturing, keeping, cultivating, especially farming. Some literatures from foreign scientists, Reimer Schefold, mentioned in his book: Mainan Roh concerning about Mentawai tradition of the existence of the three spirits: Tai Ka Bagat Koat (spirit of the sea), Tai ka Leleu (spirit of the forest and mountains) and Tai Ka Manua (spirit in the sky). 
Sabulungan, the original Mentawai tradition, is identified as one of the oldest tradition in Indonesia. 'Sa' means one or a group while 'bulung' means leaf. Figuratively, Sabulungan means a pile of leaves that has magical power known as 'kere' or 'ketsat'. The leaves that have 'kere/ketsat' are put into a 'katsila' (a circle) made from loops of sago palm leaves or sugar palm, and 'Katsila' is believed to have the three spirits; Tai Kabagat Koat, Tai Ka Leleu and Tai Ka Manua.

Some available tourism facilities and infrastructure can support the activities of tourists. Recently, there are several world class resorts such as Aloita resort in Sipora island, Karang Majat resort in Siberut island, Macaroni resort in North Pagai Island.

The easiest access to Mentawai is from Padang, the capital city of West Sumatera Province. Minangkabau international airport serves some routes of Garuda Indonesia, Lion Air, Batik Air, Sriwijaya Air and Citilink from Jakarta, Sriwijaya Air, Lion Air from Medan, Express Air from Bandung and Lion Air, Sriwijaya Air and Citilink from Batam, also Air Asia from Kuala Lumpur. Air transportation to Mentawai is provided by Susi Air from Padang to Rokot every Tuesdays, Thursdays, and Sundays. While sea transportation is provided by Ambu-Ambu ferry ship, Gambolo ferry ship departed from Bungus port, and Mentawai Fast from Muaro Padang.

Mentawai is divided into three big islands that have 10 districts areas, nevertheless, only three of them have decent ports for passenger of ASDP ships; those are Sikakap, Maileppet (South Siberut), Pokai (North Siberut) and Tuapeijat (North Sipora). The ships serve three ports once to twice a week. KMP Gambolo serves 4 destinations in a week to Padang (Bungus) Tuapeijat every Thursdays and Sundays, to Siberut every Wednesdays (all the way through to Sikabaluan), and on Fridays. While KMP Ambu-ambu serves routes from Padang (Bungus) - Sikakap on Saturdays and Tuesdays. MV. Mentawai Fast serves route from Padang (Muaro) - Tua Peijat on Mondays, 
Wednesdays, Fridays, Senin, Rabu, Jum'at while Padang (Muaro) Sikabaluan - Maileppet on Tuesdays and Saturdays.

The mileage from Padang - Mentawai by using KMP Gambolo and Ambu-ambu is about $10-12$ hours, while MV. Mentawai Fast spends about $3-4$ hours only. The distance is in normal conditions. However, when there are storms, or when the ships have to go up to dock for maintenance or repair, the number of ships that sail would decrease. The ships are only available once or twice a week or even per two months.

For local transportation, inter-island boats are ready to serve inter-island route departed from district or regency to some smaller areas. Besides the regular ships passengers may also rent a chartered ship provided by private companies. As for land transportation in Mentawai especially to Siberut, the one and only transport available is rented motorcycle. The cost depends on the mileage.

\section{Conclusion}

The potential development of tourism industry in Mentawai Islands can be increased. Besides from the oil and gas sector, tourism industry becomes another source of national income. The access to the tourism potentials that spreads in the Municipality of Mentawai Islands can be increased by paying attention on the improvement of system and infrastructure in transportation. This means tourists' visits can be elevated based on the service performance in this aspect.

Generally, the improvement of transportation system and infrastructure include:

1. Development of service by improving facilities in ports and optimizing the sea transportation modes to prepare tourism activities in open sea.

2. The expansion of the airports and increase in runway length in order to improve services for middle-sized aircrafts.

3. The improvement of transportation system and infrastructure consider the 
concept of archipelago as the geographical condition of Indonesia.

Furthermore, the orientation of infrastructure development is the improvement of sea and airways infrastructure, in this course, giving high service efficiency to the area with the natural condition as in Mentawai Islands.

The terminal objective is to optimize Indonesia tourism activities by increasing the number of tourists' visits through the gate of a well-planned transportation system.

\section{References}

Muhammadiyah, U., \& Majid, S. A. (N.D.). Formulasi Kebijakan Sistem Policy Formulation Of Sea, 3(2), 161-183.

Pendit, S Nyoman. 1994. Ilmu Pariwisata Sebuah Pengantar Perdana. Jakarta: PT Pradnya

Pgri, S., \& Barat, S. (2015). Pengaruh Daya Tarik, Fasilitas Dan Aksesibilitas Terhadap Resort Di Kab . Kep . Mentawai Alfattory Rheza Syahrul Alfattory Rheza Syahrul Pariwisata Merupakan Salah Satu Sumber Devisa Negara Selain Dari Sektor Migas Yang Sangat Potensial Dan Mempunyai Pen, 7(1), 71-82.

Pitama, I Gde Dan Putu G. Gayatri. 2005. Sosiologi Pariwisata. Yogyakarta: Penerbit ANDI.

Ricardianto, I. P., Djajaputra, D. G., \& Martono, P. D. (2017). Air Transport And Tourism In Indonesia. IOSR Journal Of Applied Chemistry, 10(5), 01-19. Https://Doi.Org/10.9790/5736-1005010119

Simarmata, J., \& Keke, Y. (2017). The Influence Of Travel Agent, Infrastructure And Accommodation On Tourist Satisfaction, 28(Ictgtd 2016), 281-283. Https://Doi.Org/10.2991/Ictgtd-16.2017.55

Suantoro, Gamal. 1997. Dasar-Dasar Pariwisata. Yogyakarta: Andi Yogyakarta

Sugiyono, 2016; Statistika Untuk Penelitian, Cetakan Ke-27, Penerbit Alfabeta, Bandung.

Sumarabawa, I. G. A. Dkk. (2013). Ketersediaan Aksesibilitas Serta Sarana Dan Prasarana Pendukung Bagi Wisatawan Di Daerah Wisata Pantai Pasir Putih, Desa Prasi, Kecamatan Karangasem. Jurnal Pendidikan Geografi, 3(1), 1-14. Retrieved From Ejournal.Undiksha.Ac.Id/Index.Php/JJPG/Article/Download/1220/108 4, Diakses 03 Juni 2017

Tambunan, N. (2009). Posisi Transportasi Dalam Pariwisata. Universitas 
Mpu Tantular, Jakarta, (Bps 2008), 39-48.

T.Hani Handoko, 2012; Manajemen, Edisi Kedua, Cetakan Keduapuluh Tiga, BPFE Yogyakarta, Yogyakarta.

----- 2011; Manajemen Kinerja, Alfabeta, Bandung. 